\title{
Mycorrhiza Enhanced Protein and Lipid Contents of Potatoes Grown on Inceptisol with Addition of Organic Matter
}

\author{
Anne Nurbaity*, Glenn Christopher Uratel and Jajang Sauman Hamdani \\ Faculty of Agriculture, Universitas Padjadjaran \\ Jl. Raya Bandung-Sumedang km.21, West Java, 45363, Indonesia \\ *e-mail: a.nurbaity@unpad.ac.id
}

Received May 16, 2018; Revised July 20, 2019; Accepted 17 September 2019

\begin{abstract}
Enhancement of productivity of potato plants grown on poor-P soil such as Inceptisols due to application of arbuscular mycorrhizal fungi (AMF) has been acknowledged. However, whether the AMF inoculation can improve the quality of potato tubers still needs further study. This study was conducted to evaluate the effectiveness of AMF in enhancing potato quality and determine whether the addition of compost and biochar to soil can support the AMF biofertilizer in enhancing the nutrient content in potato tubers. A greenhouse experiment was set up in a factorial design consisting of organic matter types (compost and compost plus biochar) and inoculation of arbuscular mycorrhiza fungi (without and with AMF consisted of Glomus sp. and Gigaspora sp.). The results showed that there was no interaction effect between organic matter and AMF on the quality of potato tubers, however, the individual factor especially AMF increased the contents of protein and lipid in the potato tubers. Application of biochar together with compost also increased the lipid content of potato tubers. The finding showed that AMF inoculation on potato seedlings grown on poor P-soil increased the quality of potato tubers.
\end{abstract}

Keywords: Inceptisols, mycorrhiza, organic matter, potato

\begin{abstract}
ABSTRAK
Peningkatan produktivitas tanaman kentang pada tanah yang kahat P seperti Inceptisols akibat aplikasi fungi mikoriza arbuskula (FMA) telah banyak diketahui. Akan tetapi, apakah FMA berpengaruh terhadap peningkatan kualitas tanaman masih perlu dilakukan. Penelitian ini bertujuan untuk mengevaluasi efektivitas FMA dalam meningkatkan kualitas tanaman kentang yang ditanam pada tanah yang diberi pupuk organik yang berbeda. Percobaan rumah kaca dengan desain faktorial yang terdiri dari dua faktor yaitu tipe bahan organik (kompos dan kompos plus biochar) dan aplikasi FMA (tanpa dan dengan FMA) telah dilakukan. Hasil percobaan menunjukkan bahwa tidak ada pengaruh interaksi antara bahan organik dan FMA terhadap kualitas kentang, namun masingmasing faktor, yaitu FMA nyata meningkatkan kandungan protein dan lemak pada umbi kentang dan biochar yang ditambahkan bersamaan dengan kompos juga meningkatkan kandungan lemak pada umbi kentang. Hasil penelitian ini memperlihatkan bahwa aplikasi FMA pada bibit kentang yang ditanam pada tanah kahat P meningkatkan kualitas umbi kentang.
\end{abstract}

Kata kunci: Inceptisols, mikoriza, bahan organik, kentang

\section{INTRODUCTION}

Potato (Solanum tuberosum L.) is one of the most important food crops in the world, which is rich in essential minerals providing both biological and nutritional values to human beings (Ekin 2011). Potato demands high level of soil nutrients for its tuber production due to relatively poor developed

J Trop Soils, Vol. 24, No. 3, 2019: 129-133

ISSN 0852-257X; E-ISSN 2086-6682 and shallow rooting system (Joshi 1997). The tremendous use of chemicals in agricultural production has deposited toxic chemicals in water and food, especially in fresh vegetables, including potatoes. As a result, there is a high demand for chemical-free foods (El-Sayed et al. 2014).

One of the solutions to reduce the use of chemicals in agriculture is by using biofertilizers contained of living microorganisms which have the ability to mobilize nutrients in soil from unavailable to available forms through biological processes 
(Ismail et al. 2014). Application of biofertilizers to soil allows the microorganisms to colonize the rhizosphere together with the plants and thus increase the supply or availability of nutrients to the host plants (Vessey 2003) as well as increase the soil fertility and crop production in sustainable farming (Wu et al. 2004, AL-Zabee and AL-Maliki 2019).

Among the soil microbial groups, the arbuscular mycorrhizal fungi (AMF) are able to establish symbiotic associations with the roots of most terrestrial vascular plants (Schüssler et al. 2001). The main role of AMF is able to increase the uptake of nutrients by host plants since the fungal hyphae act as a complementary root system, increasing the absorption area and allowing acquisition of nutrients with low mobility in soil or those are located far from the roots (Clark and Zeto 2000). The abilities of AMF to colonize their host plants and facilitate the transport of nutrients from the soil to the plant make these fungi interesting as an object of research in order to improve crop yield and soil quality (Smith and Read 2008). Enhancement of productivity of potatoes grown on P-poor soil such as Inceptisols due to application of AMF has been reported (Nurbaity et al. 2016). However, whether this biofertilizer can improve the quality of potatoes still needs further study.

The application of organic materials such as composts and biochars are able to improve soil physical and chemical characteristics enabling marginal soils to become productive soils (Hunt et al. 2010, Mahajan et al. 2019). Compost is usually enriched with different kinds of nutrients like N, P, $\mathrm{S}$ and micronutrients in order to not only speed up the decomposition process, but also to improve the quality of composts in terms of nutrient concentrations (Mahajan et al. 2019). Biochar is the carbon-rich charcoal derived from heating biomass in little or no oxygen conditions (Singh et al. 2010). The use of biochar as a soil amendment will improve soil properties with longer lasting effects than other organic materials such as compost, manure or crop residues (Youseef et al. 2017, Nurbaity and Anggraeni 2019). It has also been reported that biochar affects nutrients and microbial activity in soil (Momayezi et al. 2015).

The aim of this study was to evaluate the effectiveness of AMF in enhancing potato quality and to determine whether the application of compost and biochar on Inceptisol can support the AMF biofertilizer in enhancing the nutrient content of the potatoes.

\section{MATERIALS AND METHODS}

\section{Experimental Design}

The experiment was conducted in the Faculty of Agriculture, Universitas Padjadjaran, West Java, locating at 766 meters above sea level. The experiment was arranged in a Randomized Block Design with two factors, i.e. (1) types of organic matter (compost or compost plus biochar) and (2) AMF inoculations (without or with AMF), and three replications.

\section{Soil Samples and Treatments}

The soil samples were air dried and sieved (4 $\mathrm{mm})$. The properties of Inceptisol taken from Jatinangor, West Java is presented in Table 1. The soils were then mixed with organic materials, either compost from cow manure (the proportion of soil:compost was 2:1) or compost plus rice-husk biochar (the ratio of soil: compost: biochar was 2:1:1), and potted $10 \mathrm{~kg}$ each according to the treatments

Table 1. Characteristics of the soil used in the experiment.

\begin{tabular}{lcc}
\hline \multicolumn{1}{c}{ Parameters } & Unit & Value \\
\hline $\mathrm{pH} \mathrm{H}_{2} \mathrm{O}(1: 1)$ & $\%$ & 6.0 \\
Organic carbon & $\%$ & 2.6 \\
Total-N & $\mathrm{ppm}$ & 0.4 \\
Available-P (Bray I) & $\mathrm{mg} \mathrm{100} \mathrm{\textrm {g } ^ { - 1 }}$ & 2.5 \\
Exchangeable- $\mathrm{K}$ & $\mathrm{cmol}(+) \mathrm{kg}^{-1}$ & 18.1 \\
Cation exchange capacity & & 25.4 \\
Base Saturation & $\%$ & 65.1 \\
Sand & $\%$ & 6 \\
Silt & $\%$ & 37 \\
Clay & & 57 \\
Soil texture & & Clay \\
\hline
\end{tabular}


as shown in the experimental design. The physical characteristics of the soil that has been added with organic matter according to the treatments as growing media is presented in Table 2 .

\section{Inoculation of Arbuscular Mycorrhizal Fungi}

Arbuscular mycorrhizal fungi used in this experiment were Glomus sp. and Gigaspora sp. Twenty five grams of mycorrhizal inoculum (granular zeolite carrier contained about 50 spores of Glomus sp. and Gigaspora sp. per gram) were incorporated in each pot at the day of planting. The mycorrhizal inoculum was placed in the planting hole at the depth of $10 \mathrm{~cm}$ from the surface, followed by certified potato seed-tubers of Medians cultivar, and subsequently covered with a layer of soil in the pots containing $10 \mathrm{~kg}$ of soil. Seedlings were grown for 12 weeks under greenhouse condition with natural light interception, and watered every day to maintain $80 \%$ of soil water holding capacity.

\section{Analysis of Potato Tubers}

The potato tubers were analysed to determine the water content (oven method), ash content (dryashing method), protein content (Kjeldhal method), lipid content (Soxhlet method) and carbohydrates (by difference).

\section{Data Analysis}

The data from the treatments were compared using the F-test at 5\% significance level followed by the Duncan's Multiple Range Test at 5\% significance level.

\section{RESULTS AND DISCUSSION}

The results of the analysis of variance showed that no significant difference on the potato tuber moisture contents among the treatments of organic matter and mycorrhiza (Table 3). Both biochar and compost applications resulted in similar effects on this paramater. Chan et al. (2008) indicated that biochar and compost applications improved soil physical properties such as bulk density, total porosity, drainage pores, water content, and permeability.

Jeffery et al. (2011) showed that compared to the control treatment, the biochar application resulted in the greatest effect on acidic (14\%) and neutral $\mathrm{pH}$ soils $(13 \%)$ and on soils with a coarse $(10 \%)$ or medium texture $(13 \%)$. The results suggested the three main benefits of biochar addition to the soil include a liming effect (increased $\mathrm{pH}$ ) and improved water holding capacity and nutrient availability. Rice husk biochar could be used as a substitution for lime materials to increase the $\mathrm{pH}$ of acidic soils. A lot of works have shown that biochar is able to improve soil properties, including soil aggregation, soil water holding capacity and soil strength and to increase soil organism population and activity (Rondon et al. 2007, Nurbaity et al.2013). Furthermore, the treatments also showed similar effects on ash contents of potato tubers (Table 2). Clearly both compost and biochar resulted in the same ash contents of potato tubers. Biochar caused a significant increase in microbial efficiency as a measure of units of $\mathrm{CO}_{2}$ released per microbial

Table 2. Some physical characteristics of growing media of potato plants used in the experiment.

\begin{tabular}{lccc}
\hline \multicolumn{1}{c}{ Growing Medium } & $\begin{array}{c}\text { Bulk Density } \\
\left(\mathrm{kg} \mathrm{L}^{-1}\right)\end{array}$ & $\begin{array}{c}\text { Porosity } \\
(\%)\end{array}$ & $\begin{array}{c}\text { Water Holding Capacity } \\
(\%)\end{array}$ \\
\hline soil + cow manure compost & 0.79 & 43 & 17 \\
soil + cow manure compost + rice husk biochar & 0.67 & 52 & 16 \\
\hline
\end{tabular}

Table 3. The Effects of organic matter and mycorrhiza applications on water and ash contents of potato tubers.

\begin{tabular}{ccc}
\hline Treatments & Water (\%) & Ash (\%) \\
\hline Organic Matter & & \\
Compost & 83.2 & 1.43 \\
Compost + Biochar & 83.6 & 1.38 \\
Mycorrhiza Inoculation & & \\
Without mycorrhiza & 83.7 & 1.36 \\
With mycorrhiza & 83.1 & 1.45 \\
\hline
\end{tabular}


Table 4. Effect of organic matter and mycorrhiza applications on protein, lipid and carbohydrate contents of potato tubers.

\begin{tabular}{lccc}
\hline Treatments & $\begin{array}{c}\text { Protein } \\
(\%)\end{array}$ & $\begin{array}{c}\text { Lipid } \\
(\%)\end{array}$ & $\begin{array}{c}\text { Carbohydrate } \\
(\%)\end{array}$ \\
\hline Organic Matter & & & \\
Compost & $1.91 \mathrm{a}$ & $0.08 \mathrm{a}$ & $13.40 \mathrm{a}$ \\
Compost + Biochar & $1.94 \mathrm{a}$ & $0.16 \mathrm{~b}$ & $12.90 \mathrm{a}$ \\
$\begin{array}{c}\text { Mycorrhiza Inoculation } \\
\text { Without mycorrhiza }\end{array}$ & & & \\
With mycorrhiza & $1.57 \mathrm{a}$ & $0.03 \mathrm{a}$ & $13.30 \mathrm{a}$ \\
\hline
\end{tabular}

The numbers followed by different letters in the same column show significant difference according to the Duncan Multiple Range Test at $p<0.05$.

biomass carbon in soil (Kolb et al. 2009). Yamamoto et al. (2006) further indicated that the increase of amount and colonization rate of arbuscular mycorrhizal fungi was observed on maize roots after biochar application. A more rapid cycling of nutrients in soil organic matter and microbial biomass as well as better colonization of roots by arbuscular mycorrhizal fungi will improve water holding capacity, nutrient availability and crop yields.

The interaction between organic matter and AMF biofertilizer showed no significant differences $(p<0.05)$ on the protein, lipid and carbohydrate contents of potato tubers. However, the contents of protein and lipid of potato tubers in the AMF biofertilizer treatment is higher than in the control treatment (without AMF biofertilizer). Furthermore, the lipid content of potato tubers applied with compost + biochar is higher compared to that in the compost treatment (Table 4).

Higher protein content after application of AMF biofertilizer is supported by the findings of Utomo $e t$ al. (2011) which indicated that the availability of $\mathrm{N}$ in soil increased after AMF biofertilizer application. Further elaboration explained that protein is an essential compound in food, in which its concentration in plants is highly dependent on $\mathrm{N}$ availability in soil at sowing time, $\mathrm{N}$ released during the growing seasons through mineralization of soil organic matter and $\mathrm{N}$ applied as organic or inorganic fertilizer. The increase in the protein content in the potato tubers due to AMF presence seems often to be observed, since such protein increments due to AMF presence in roots have been reported regularly in previous studies (Miransari 2010). Adavi and Tadayoun (2014) showed that mycorrhizal plants were more successful than non-mycorrhizal plants in transportation of assimilates from source to sink parts and produced high tuber protein.

Inoculation of AMF biofertilizer significantly increased lipid content of potato tubers. In arbuscular mycorrhizal fungi, vesicles serve as carbon storage compartments for the fungi and are rich in lipids. The development of vesicles depends on the environmental conditions such as high or low $\mathrm{P}$ availability in soil (Smith and Read 2008). Both the increase of $\mathrm{N}$ and P uptake are influenced by AMF, thus contributing to the increase of lipid content in potato tubers. The results of the current study showed that the quality of potatoes in term of protein and lipid contents are significantly higher in the mycorrhizal plants compared to non-mycorrhizal plants.

\section{CONCLUSIONS}

There was no interaction effects between organic matter and mycorrhiza on the quality of potato tubers, however, the individual factor especially application of mycorrhiza increased the content of protein and lipid in potato tubers. Biochar application together with compost also increased the lipid content in potato tubers.

\section{ACKNOWLEDGEMENTS}

This project was financially supported by The Academic Leadership Grant Universitas Padjadjaran. Authors would like to extend high appreciation to the Rector of Universitas Padjadjaran through the Directorate of Research Universitas Padjadjaran.

\section{REFERENCES}

Adavi Z and Tadayoun M R. 2014. Effect of mycorrhiza application on plant growth and yield in potato production under field condition. Iran J Plant Phys 43: 1087-1093.

Al-Zabee M and S Al-Maliki. 2019. Interactions between Biofertilizers and Chemical Fertilizers affected Soil Biological Properties and Potato Yield. Euphrates J Agric Sci 11: 1-13. 
Chan KY, BL van Zwieten, I Meszaros, D Downie and S Joseph. 2008. Using poultry litter biochars as soil amendments. Aus J Soil Res 46: 437-444.

Clark RB and SK Zeto. 2000. Mineral acquisition by arbuscular mycorrhizal plants. J Plant Nutr 23: 867-902.

Ekin Z. 2011. Some analytical quality characteristics for evaluating the utilization and consumption of potato (Solanum tuberosum L.) tubers. Afr J Biotech 10: 6001-6010.

Hunt J, M DuPonte, D Sato and A Kawabata. 2010. The basics of biochar: a natural soil amendment. Soil Crop Manage 30: 1-6.

Ismail A, M Riaz, S Akhtar, T Ismail, MAmir and M Zafarul-Hye. 2014. Heavy metals in vegetables and respective soils irrigated by canal, municipal waste and tube well water. Food Addit Contam Part B 7: 213-219.

Jeffery S, F G A Verheijen, M van der Velde and AC Bastos. 2011. Quantitative review of the effects of biochar application to soils on crop productivity using metaanalysis. Agric Ecosyst Environ 144: 175-187.

Joshi D. 1997. Soil fertility and fertilizer use in Nepal. Soil Science Division, Nepal Agricultural Research Council (NARC), Khumaltar, Lalitpur, Nepal. 82 pp.

Kolb SE, KJ Fermanich and ME Dornbush. 2009. Effect of charcoal quantity on microbial biomass and activity in temperate soils. Soil Sci Soc Am J 73: 1173-1181.

Mahajan NC, K Mrunalini, KS Krishna Prasad, RK Naresh and L Sirisha. 2019. Soil quality indicators, building soil organic matter and microbial derived inputs to soil organic matter under conservation agriculture ecosystem: a review. Int J Curr Microbiol App Sci 8: 1859-1879.

Miransari M. 2010. Contribution of arbuscular mycorrhizal symbiosis to plant growth under different types of soil stress. Rev Plant Biol 12: 563-569.

Momayezi M, RC Pereira and R Self. 2015. Biochar and mycorrhizal fungi influence on nutrient uptake by two pasture species in New Zealand. Int J Biosci 6: 52-60.

Nurbaity A and DS Anggraeni. 2019. Biochar arang sekam dan pemanfaatannya. In: T Simarmata (ed). Pemanfaatan limbah pertanian. Buku Materi Pokok LUHT 4450 Modul Universitas Terbuka, 3.1-3.49. (in Indonesian).
Nurbaity A, C Hidayat, D Hudaya and JS Hamdani. 2013. Mycorrhizal fungi and organic matter affect some physical properties of Andisols. Soil Water $J 2$ : 639-644.

Nurbaity A, ET Sofyan and JS Hamdani. 2016. Application of Glomus sp. and Pseudomonas diminuta reduce the use of chemical fertilizers in production of potato grown on different soil types. IOP Conf Ser: Earth Environ Sci 41(1) 012004.

Rondon MA, J Lehmann, J Ramirez and M Hurtado. 2007. Biological nitrogen fixation by common beans (Phaseolus vulgaris L.) increases with biochar additions. Biol Fertil Soils 43: 699-708.

Sayed F El-Sayed, HA Hassan, M;M El-Mogy and A Abdel-Wahab. 2014. Growth, yield and nutrient concentration of potato plants grown under organic and conventional fertilizer systems. Am-Eur J Agric Environ Sci 14: 636-643.

Schüssler AD, C Schwarzott, C Walker. 2001. Anew fungal phylum, the Glomeromycota: phylogeny and evolution. Mycol Res 103:1413-1421.

Singh B P, B J Hatton, B Singh, A L Cowie, A Kathuria 2010. Influence of biochars on nitrous oxide emission and nitrogen leaching from two contrasting soils. $J$ Environ Qual 39: 1-12.

Smith SE and DJ Read. 2008. Mycorrhizal Symbiosis. 2nd ed. Academic Press, 605 pp, San Diego and London.

Vessey JK. 2003. Plant growth-promoting rhizobacteria as bio fertilizers. Plant Soil 255: 571-586.

Wu SC, ZH Cao, ZG Li, KC Cheung, and MH Wong. 2004. Effects of bio fertilizer containing N-fixer, $\mathrm{P}$ and $\mathrm{K}$ solubilizers and AM fungi on maize growth: a greenhouse trial. Geoderma 125: 155-166.

Yamamoto H, H Komekado and A Kikuchi. 2006. Caveolin is necessary for Wnt-3a-dependent internalization of LRP6 and accumulation of b-catenin. Dev Cell 11:213-22.

Youseef M E A, IAS Al-Easily and DAS Nawar . 2017. Impact of biochar addition on productivity and tubers quality of some potato cultivars under sandy soil conditions. Egypt J Hort 44: 199-217. 